King of Hearts 



\title{
King of Hearts
}

\section{Drag Kings in the American South BAKER A. ROGERS}$$
\text { [i] }
$$ \\ Rutgers University Press \\ New Brunswick, Camden, and Newark, New Jersey, and London
}




\section{Library of Congress Cataloging-in-Publication Data}

Names: Rogers, Baker A., author.

Title: King of hearts : drag kings in the American South / Baker A. Rogers.

Description: New Brunswick : Rutgers University Press, 202I. |

Includes bibliographical references and index.

Identifiers: LCCN 2021006634 | ISBN 978197882053I (paperback) |

ISBN 9781978820548 (cloth) | ISBN 9781978820555 (epub) |

ISBN 9781978820562 (mobi) | ISBN 9781978820579 (pdf)

Subjects: LCSH: Male impersonators-Southern States-History. |

Gender expression-Southern States.

Classification: LCC PN2071.I47 R63 202I | DDC 792.02/8-dc23

LC record available at https://lccn.loc.gov/2021006634

A British Cataloging-in-Publication record for this book is available from the British Library.

\section{Copyright (C) 2022 by Baker A. Rogers}

All rights reserved

No part of this book may be reproduced or utilized in any form or by any means, electronic or mechanical, or by any information storage and retrieval system, without written permission from the publisher. Please contact Rutgers University Press, ro6 Somerset Street, New Brunswick, NJ o89or. The only exception to this prohibition is "fair use" as defined by U.S. copyright law.

The paper used in this publication meets the requirements of the American National Standard for Information Sciences-Permanence of Paper for Printed Library Materials, ANSI Z39.48-I992.

www.rutgersuniversitypress.org

Manufactured in the United States of America 
For everyone who thinks that gender is a drag. 
